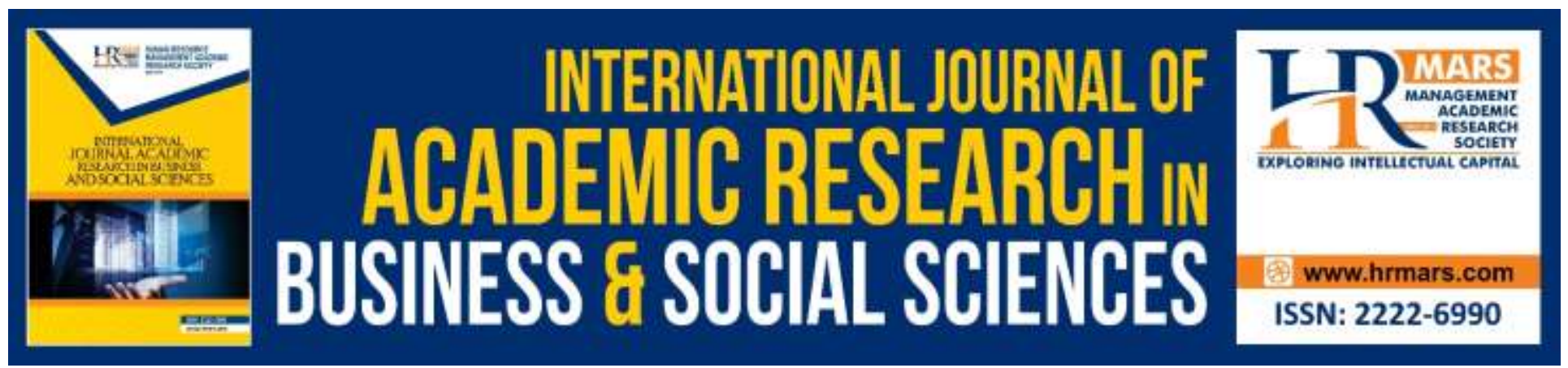

\title{
Determining the Reliability of the Emotional Competency Module on Malaysian Adolescents
}

Asma Perveen, Hazalizah Binti Hamzah, Azizah Othman, Nurul Ain Hidayah Abas, Pau Kee, Nurul, Ain Binti Mohd Daud, Ebru Morgul, Pavithrah Jaya Kumar

To Link this Article: http://dx.doi.org/10.6007/IJARBSS/v9-i7/6092 DOI: $10.6007 /$ IJARBSS/v9-i7/6092

Received: 02 May 2019, Revised: 17 June 2019, Accepted: 30 June 2019

Published Online: 12 July 2019

In-Text Citation: (Perveen et al., 2019)

To Cite this Article: Perveen, A., Hamzah, H. B., Othman, A., Abas, N. A. H., Kee, P., Daud, A. B. M., ... Kumar, P. J. (2019). Determining the Reliability of the Emotional Competency Module on Malaysian Adolescents. International Journal of Academic Research in Business and Social Sciences, 9(7), 65-76.

\section{Copyright: (c) 2019 The Author(s)}

Published by Human Resource Management Academic Research Society (www.hrmars.com)

This article is published under the Creative Commons Attribution (CC BY 4.0) license. Anyone may reproduce, distribute, translate and create derivative works of this article (for both commercial and non-commercial purposes), subject to full attribution to the original publication and authors. The full terms of this license may be seen at: http://creativecommons.org/licences/by/4.0/legalcode

$$
\text { Vol. 9, No. 7, 2019, Pg. } 65 \text { - } 76
$$

Full Terms \& Conditions of access and use can be found at http://hrmars.com/index.php/pages/detail/publication-ethics 


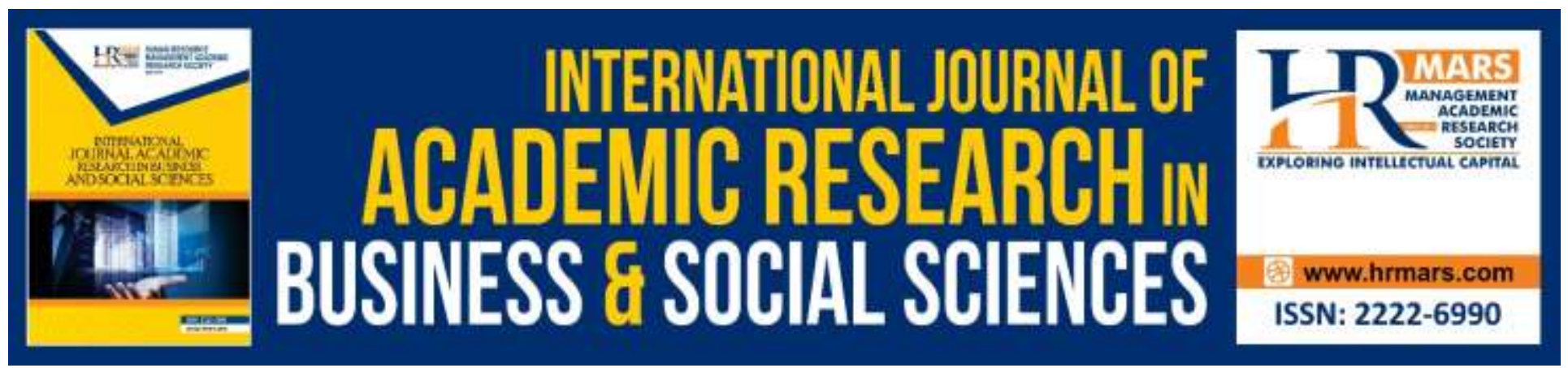

\section{Determining the Reliability of the Emotional Competency Module on Malaysian Adolescents}

\section{Asma Perveen ${ }^{1}$, Hazalizah Binti Hamzah², Azizah Othman³ ${ }^{3}$ Nurul Ain Hidayah Abas ${ }^{4}$, Pau Kee ${ }^{5}$, Nurul, Ain Binti Mohd Daud, ${ }^{6}$ Ebru Morgul $^{7}$, Pavithrah Jaya Kumar ${ }^{8}$}

12456 Department of Psychology and Counselling, Faculty of Human Development, Sultan Idris Education University (UPSI), Malaysia, ${ }^{3}$ Department of Pediatrics, School of Medical Sciences, Universiti Sains Malaysia (USM) Malaysia, ${ }^{7}$ Department of Psychology, Ibn Haldun University, Turkey

${ }^{8}$ Masters in Science (Psychology), Sultan Idris Education University (UPSI), Malaysia

Abstract: This study aims to examine the effectiveness of the Emotional Competency Module developed specifically for adolescents in Malaysia to help address the huge delinquent behavior cases in Malaysia. Method: This module is one of the modules that was developed based on Daniel Goleman's four emotion competency constructs. The module reliability instrument was developed based on the objectives of the activities in the module. A pilot test was conducted to measure the reliability of the module. After the pilot test, 19 participants were asked to answer the module reliability instrument and later on a Cronbach's alpha value was analysed. Results: All the four domains and the overall module activities items showed very high reliability values. The reliability value showed that the module had a Cronbach's alpha of 0.968 to 0.826 . The reliability value of the overall module was 0.985 . Implications: The findings of the study suggest that the module is effective for adolescents as each activity successfully achieved its objectives. This module also serves as a guideline for psychologists, counsellors and teachers to provide emotional competence training for adolescents. This study provides a new module to train emotional competency specifically for adolescents in Malaysia. Study is significant to provide and prove a new ECM module activities for youngster to improve their emotional well-being.

Keywords: Emotional Competency, Module, Reliability, Adolescents, Daniel Goleman

\section{Introduction}

Adolescents are defined as those aged between 10 to 24 years old (Curtis, 2015). This is a phase of life when teenagers struggle to find their self-identity and begin to explore the world. Their curiosities are at it's best at this age. It is at these age that they would require more attention and care from their parents and the people surrounding them. A previous study showed that delinquent behaviours 
were lower in those with good emotional intelligence (Abdullah, Lee, Roslan and Baba, 2015). Adolescents with low emotional intelligence are more susceptible to delinquent behaviours. These behavioural problems arise due to many reasons. Some of them are due to the many life challenges and distress that cause them to become unhappy and dissatisfied as youths and commit serious behavioural misconducts such as gangsterisme, bullying, drug abuse, sexual misconduct and crime (Hashim, 2007). Meanwhile, a study by Perveen et al., (2018) showed that most adolescents in Malaysia scored average in emotional intelligence in a survey using the Universiti Sains Malaysia Emotional Quotient Inventory (USMEQ-i) indicating that adolescents were not completely emotionally competent and that they are poor in managing their emotions when under pressure (Bahri, et al., 2010).

Consequently, to overcome adolescent emotional and behavioural problems, the Emotional Competency Module was developed which aimed to enhance the overall emotional competence of adolescents in Malaysia. A previous qualitative study by Perveen et al., (2018) showed that adolescents in Malaysia had a wide range of factors affecting their emotional issues such as their living environment, lack of self-acceptance amongst many others. This current study aimed to test the effectiveness of the newly developed Emotional Competency Module.

The module was developed based upon Daniel Goleman's (2001) four emotional competence constructs which are self-awareness, self-management, social awareness and relationship management. The activities are as listed in Table 1. There are three ice breaking activities, six selfawareness domain activities, eight self-management activities, five social awareness activities and five relationship management activities. Figure 1 shows a framework of the module contents.

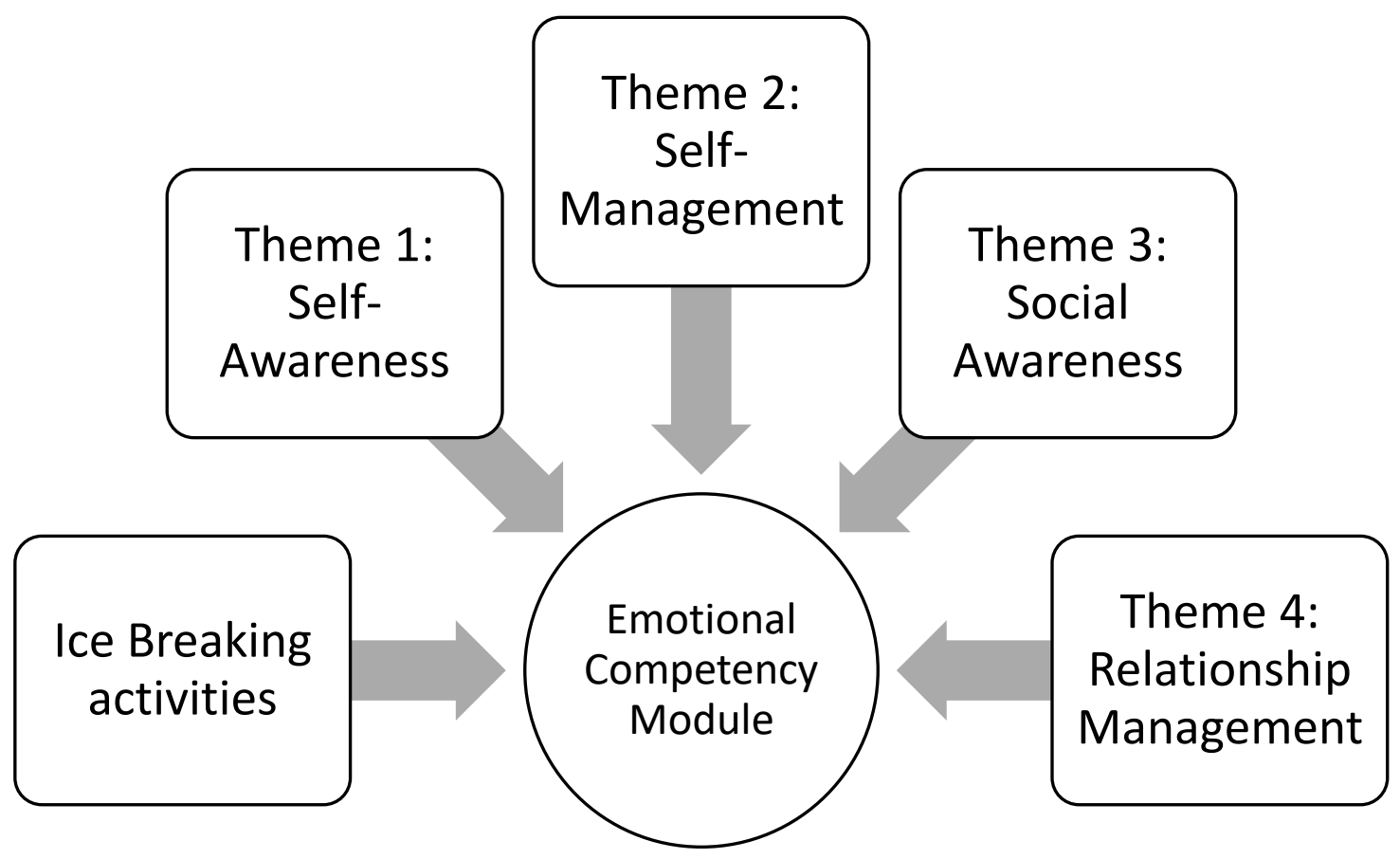


INTERNATIONAL JOURNAL OF ACADEMIC RESEARCH IN BUSINESS AND SOCIAL SCIENCES

Vol. 9, No. 7, July, 2019, E-ISSN: 2222-6990 @ 2019 HRMARS

\section{Figure 1: Contents of the Emotional Competency Module}

The Emotional Competency Module is essential for addressing a wide range of adolescent emotional problems. A rating scale is developed to test the module effectiveness. The reliability of the the Emotional Competency Module was analyzed. Some of the research questions of this study are as stated below:

i. Is there any evidence of reliability for the Emotional Competency Module?

ii. Is there any evidence of reliability for Domain 1: Self Awareness?

iii. Is there any evidence of reliability for Domain 2: Self-management?

iv. Is there any evidence of reliability for Domain 3: Social Awareness?

v. Is there any evidence of reliability for Domain 4: Relationship Management?

\section{Literature Review}

There are various kinds of emotional issues that capture the attention of many parties. Nareman Aly Mohamed, Nagwan Mohamed Madbouly and Eman A. Monem A. Rashid (2017) conducted a study on the effect of emotional intelligence enhancement program on suicidal ideations, among attempted suicide adolescents which found that such emotional intelligence enhancing programs could improve depression and emotional intelligence.

Meanwhile, other studies also indicate that emotional intelligence programs or trainings were potentially good in enhancing overall emotional intelligence (Dolev \& Leshem, 2017; Castillo \& Fisher, 2017; Motamedi, Ghobari-Bonab, Beh-pajooh, Yekta, \& Afrooz, 2017; Vijayalaxmi \& Kadapatti, 2013). Similarly, enhancing emotional intelligence has been shown to improve behaviours (Dolev \& Leshem, 2017), improve the life quality of mothers with children with leukaemia illness (Taghizadeh, Masoompour, \& Shrinabadi, 2017), reducing the usage of aggression to solve conflicts violence among adolescence to prevent violence (Garaigordobil \& Pena-Sarrionandia, 2015), predict significant changes in confusion, perceived stress, mental health, somatic complaints and vigor (Hodzic, Ripoll, Bernal, \& Zenasni, 2015).

Existing research by Zijlmans, Embregts, Gerits, Bosman, \& Derksen (2014) showed that emotional training could increase task-oriented coping. On the other hand, a modest improvement in family communication, satisfaction, emotional intelligence as well as a slight improvement in perspective taking and anger expression were also revealed in a study (Platsidou \& Tsirogiannidou, 2016).

Several activities were more commonly used in emotional intelligence training. Some of them focused on emotional self-control, emotional self-motivation, purification of emotions and selfaffections expressiveness training which had significant effects on social adjustment and social intimacy of women with breast cancer (Mahdavi et al., 2015). Other studies such as one by Castillo and Fisher (2017) recommended expressive writing and deep breathing. In addition, social and emotional learning intervention is effective among Spanish academic contexts (Castillo, Salguero, Fernández-Berrocal, \& Balluerka, 2013). 
A qualitative study that identifies emotional issues faced by Malaysian youths revealed several domains which are professional competence, living environment (negative lifestyle, family background, education system and social media), relationship management (express emotions, communication, problem solving), social awareness (interpersonal relationship), self-management (motivation, maturity, controlling emotion, stress management), self-awareness (psycho-biology of emotions, emotion regulation, lack of self-acceptance, understanding emotions), institution negative (Future plan, lack volition, punishment, caretaker assertiveness, away from family, stuck here, tight schedule, stress, death of parents, feeling sad), institution positive (positive change, talking straight to the point, scheduled work, unity-brotherhood, learning skills) and ways of coping (interpersonal skills, suggestions for module, healthy activities, teaching social intelligence, parenting skills, emotional management skills, self-awareness skills, social religious values and respect, counselling) (Perveen, et al., 2018).

This enhancing module was designed specifically to address the emotional and behavioural issues experienced by Malaysian adolescents. Meanwhile, plenty of studies have focused on issues such as the development of a career exploration module by Talib, Mohamad and Wahab (2015) for which the module has high validity and reliability and drug addiction modules (Ahmad, Hassan \& Abidin, 2008; Ahmad, Mat, Yahaya, Yusof \& Alias, 2011). Therefore, it is crucial to address a different aspect of adolescents which focuses on improving the emotional competence of adolescents. Many of the research focus on intervention, program or training-based research. Some of the researches were investigating the role of emotional intelligence many different types of issues among adolescence, adult and other significant population. However, module development on emotional intelligence is unfamiliar among local research. Therefore, a comprehensive module as a management tool to handle emotional issues among adolescence is highly in need.

\section{Methodology}

This research is a design and development-based research which has three phases. Phase one: Preliminary study involving a quantitative and qualitative study The study involved 262 participants for the quantitative study and 15 interviews were conducted with counsellors and 13 interviews were conducted with students from 5 Tunas Bakti juvenile schools, 6 national secondary schools from 5 different states (Selangor, Kuala Lumpur, Perak, Terengganu and Melaka) and 4 universities in Malaysia using purposive sampling. Phase two: Module development based on need analysis of phase one. Phase three: Module reliability and pilot test. The part of reliability is the main focus of this research paper.

The rating scale consisting of 131 items was constructed to receive the feedback of the participants during the pilot test. The instrument underwent back-to-back translation and was face validated by professionals as well as university students. Before proceeding to construct the reliability rating scale, it is important to review a suitable framework to properly measure the reliability of the module activities. Russell (1974) stated that all the steps included in the activity needs to be followed thoroughly to measure the reliability of a module. If successful, it means participants master the objective of the intervention (i.e. activity). Therefore, Ahmad and Noah (2005) suggested to measure the reliability value index of a module using the items of either the activity objectives or procedure 
which will be included into a questionnaire. As a result, the rating scale items were constructed based on the objectives and procedures of each activity in the module.

The items in the rating scale are rated using a 10-point Likert scale with 0 stating that the person 'Strongly Disagree' that the item for the said activity is not suitable for their respective domain and 10 referring that the person 'Strongly Agree' that the item for the said activity is very suitable for the respective domain in the Emotional Competency Module. An example of an item for the 'The Emotional Brain' activity in the self-awareness domain is "The activity was suitable in enhancing your understanding about the physical attributes of emotions" and "The activity enhances your awareness towards different physical attributes of the emotion". Meanwhile, an example of the 'Emotional Map' activity from the self-management domain is "The activity enhances understanding situations that can cause emotions". Another example of an item for the social awareness domain activity, 'Empathy', is "This activity enhances your awareness towards other people's feelings in different situations". Similarly, the 'Sherlocking' activity in the relationship management domain has different items evaluating it's objectives for example, "The activity can enhance your ability to identify verbal communication methods".

Thirty university students were initially recruited to join the pilot program of the module. They were chosen through convenient sampling. An advertisement was posted with the university's permission to recruit the participants for this pilot test. All 28 activities in the module were implemented in the two-day program. However, only 19 participants showed up for both days of the program. All participants were asked to answer the rating scale to rate the suitability of each activity in the module in enhancing their emotional competency.

\section{Results}

The internal consistency of each activity items in the rating scale were analysed and reported in Table 1. 
INTERNATIONAL JOURNAL OF ACADEMIC RESEARCH IN BUSINESS AND SOCIAL SCIENCES

Vol. 9, No. 7, July, 2019, E-ISSN: 2222-6990 (c) 2019 HRMARS

Table 1: Reliability Analysis Results

\begin{tabular}{|c|c|c|c|}
\hline Activity & $\begin{array}{l}\text { Cronbach's } \\
\text { Alpha }\end{array}$ & $\begin{array}{c}\text { Cronbach's Alpha } \\
\text { Based on } \\
\text { Standardized Items }\end{array}$ & $\begin{array}{l}\mathrm{N} \text { of } \\
\text { Items }\end{array}$ \\
\hline \multicolumn{4}{|l|}{ Ice Breaking Activities } \\
\hline Name String-Ice Breaker & 0.924 & 0.926 & 4 \\
\hline Cip, Cap, Cop-Ice Breaker & 0.923 & 0.924 & 6 \\
\hline Finding Emotions-Ice Breaker & 0.928 & 0.933 & 6 \\
\hline Domain 1: Self-awareness & 0.986 & 0.987 & 42 \\
\hline $\begin{array}{l}\text { The Emotional Brain: Psycho-biology of } \\
\text { emotions }\end{array}$ & 0.956 & 0.956 & 6 \\
\hline Emoticons: Understanding emotions & 0.938 & 0.938 & 6 \\
\hline ABC: Emotion rationalization & 0.942 & 0.943 & 6 \\
\hline This Is Me: Self-acceptance & 0.951 & 0.952 & 6 \\
\hline Triple Vision: Self-efficacy/Resilience & 0.954 & 0.955 & 5 \\
\hline The Best Version of Yourself: Self-esteem & 0.923 & 0.927 & 7 \\
\hline Domain 2: Self-management & 0.980 & 0.983 & 34 \\
\hline Emotional Map-Emotion regulation & 0.959 & 0.959 & 7 \\
\hline $\begin{array}{l}\text { Breathing Technique-Controlling } \\
\text { emotions }\end{array}$ & 0.826 & 0.841 & 2 \\
\hline $\begin{array}{l}\text { Progressive Muscle Relaxation-Stress } \\
\text { management }\end{array}$ & 0.895 & 0.895 & 2 \\
\hline Pop!-Stress management & 0.938 & 0.941 & 3 \\
\hline Pressure Cooker-Stress management & 0.942 & 0.942 & 5 \\
\hline $\begin{array}{l}\text { Time Flies-Stress management/Time } \\
\text { management }\end{array}$ & 0.939 & 0.941 & 4 \\
\hline My Spiritual Coping-Stress management & 0.934 & 0.936 & 4 \\
\hline Move It-Self-motivation & 0.932 & 0.933 & 3 \\
\hline Domain 3: Social awareness & 0.980 & 0.981 & 20 \\
\hline One Day: Social responsibility & 0.947 & 0.948 & 4 \\
\hline Empathy: Empathy & 0.949 & 0.950 & 5 \\
\hline Colourful Emotions: Empathy & 0.946 & 0.947 & 3 \\
\hline Life Tree: Social respect & 0.943 & 0.943 & 4 \\
\hline Colours of Malaysia: Social respect & 0.928 & 0.928 & 4 \\
\hline Domain 4: Relationship management & 0.982 & 0.982 & 19 \\
\hline Sherlocking: Communication skills & 0.967 & 0.968 & 6 \\
\hline Let's Win: Assertive skills & 0.907 & 0.909 & 3 \\
\hline Maze Runner: Teamwork & 0.962 & 0.965 & 4 \\
\hline $\begin{array}{l}\text { Rabbits and Hyenas: Dealing with } \\
\text { criticism }\end{array}$ & 0.956 & 0.957 & 4 \\
\hline Sorry Sorry: Emotion expression & 0.956 & 0.957 & 2 \\
\hline Overall module & 0.985 & 0.985 & 131 \\
\hline
\end{tabular}


Table 1 shows that all the activities were reported to have high reliability in achieving it's objectives in enhancing every aspect of a person's emotional competence with the highest being reported to have a Cronbach's alpha at 0.968 (Sherlocking-Communication skills) and the lowest with 2 items $(\alpha=0.826)$ which is the Deep Breathing (Controlling emotions) activity. This shows that communication skills were the most effective in enhancing emotional competency skills. This is similar to a previous study by Perveen et al., (2018) which showed that healthy activities like the ice breaker activities can help cope with emotional issues.

Similarly, the domain with the highest reliability index was the self-awareness domain (42 items; $\alpha=0.986$ ). This is followed by relationship management domain (19 items; $\alpha=0.982$ ) and also social awareness (20 items; $\alpha=0.980$ ). and self-management domain which had equal reliability index (34 items; $\alpha=0.980$ ).

\section{Discussion}

\section{Research Question 1: Is there any evidence of reliability for the Emotional Competency Module?}

All the domains showed high reliability. The overall module evaluation instrument had 131 items $(\alpha=0.985)$. Hence, it was found that the Emotional Competency Module was highly reliable. This is similar to many previous studies which showed that emotional intelligence training can indeed enhance emotional intelligence (Vijayalaxmi \& Kadapatti, 2013; Castillo \& Fisher, 2017; Motamedi, Ghobari-Bonab, Beh-pajooh, Shokoohi Yekta, \& Afrooz, 2017).

\section{Research Question 2: Is there any evidence of reliability for Domain 1: Self Awareness?}

Results showed that the module had high reliability in which the self-awareness domain had 42 items $(\alpha=0.986)$. The self-awareness domain in the module which consisted of activities focusing on the psycho-biology of emotions, understanding emotions, emotion rationalization, self-acceptance and self-esteem are all effective in enhancing emotional competence. The Emotional Brain activity has the highest alpha value of 0.956 whereas the self-esteem activity has the lowest Cronbach's alpha value with 7 items $(\alpha=0.923)$. This is also similar to previous studies by Perveen et.al (2018). Goleman (2001) also stated that knowing the neurological substrates function of the body such as in the psycho-biology of emotion activity is important in emotion intelligence enhancement. Besides, studies by Toyota (2011) showed there was a relationship between emotional intelligence with selfacceptance and self-esteem (Toyota et.al., 2007). Hence, enhancing the self-acceptance and selfesteem can both enhance overall emotional intelligence.

\section{Research Question 3: Is there any evidence of reliability for Domain 2: Self-management?}

The self-management domain was found to be highly reliable (34 items; $\alpha=0.980$ ). The activity with the highest reliability score in this domain is the 'Emotional Map' activity with 7 items $(\alpha=0.959)$ and the breathing technique activity with 2 items $(\alpha=0.826)$. Goleman (2001) states that emotion regulation skill is vital for enhancing emotional intelligence skills. Meanwhile Castillo and Fisher (2017) also showed that deep breathing activity is effective in enhancing emotional intelligence. 


\section{Research Question 4: Is there any evidence of reliability for Domain 3: Social Awareness?}

At the same time, the Cronbach's alpha for the social awareness domain was 0.980 . The empathy activity (Emotional Map) which focuses on an art activity in which the participants are asked to draw a mind map to evaluate the primary and secondary emotions involved in a single stressful situation scored the highest Cronbach's alpha with 3 items $(\alpha=0.949)$ whereas the social respect activity scored the lowest ( 4 items; $\alpha=0.928$ ). This is supported by Hajibabaee et.al. (2018) who showed that there was a positive correlation between empathy and emotional intelligence. Hence increasing empathy could also enhance emotional intelligence. Meanwhile, a study by Perveen et.al (2018) showed that social respect was one of the emotional issues faced by youths which was addressed in this module therefore, supported.

Research Question 5: Is there any evidence of reliability for Domain 4: Relationship Management? The Cronbach's alpha for the fourth domain which is the relationship management domain was 0.982. The Sherlocking activity scored the highest ( 6 items; $\alpha=0.967$ ) whereas assertive skills (3 items; $\alpha=0.907$ ) activity scored lowest in the relationship management domain. Communication skills is an important skill in enhancing emotional intelligence (Goleman, 2001). Those with good emotional intelligence also possesses good communication skills (Najib, Che Su \& Zarina, 2015). Meanwhile, Noghabaei and Azar (2015) showed that assertiveness training significantly increases emotional intelligence. Therefore, these previous studies support the current study that communication skills such as 'Sherlocking' are good in improving overall emotional intelligence.

\section{Limitations, Implications and Future Recommendations Limitations and Future Recommendations}

In summary, the newly developed module for adolescents in Malaysia, is found to be reliable. Hence, further studies to test it's interventional-designed study to see it's potential to enhance positive behaviours as well as overall emotional competency of a person is crucial.

\section{Implications}

The findings of the research can help provide better knowledge regarding more current issues of emotional problems faced by adolescents in Malaysia. Besides the results cater youth organizations and governmental organizations to modify their approaches toward the improvement of developing youth skills in this era. The results also show specific emotional competency issues faced by adolescents for which the Emotional Competency Module is developed. This module will benefit all professionals and adolescents in handling their emotions in future.

\section{Conclusion}

The pilot test revealed that the module has a high Cronbach's alpha of 0.985. As Russell (1974) mentions that a module is reliable if all the objectives and steps in the module are met. Therefore, this indicates that the Emotional Competency Module can enhance the emotion competence of adolescents.

The findings of the study indicated that the module is effective to increase emotional competency among youngsters by involving them in the activities of the four domains in the module. The self- 
awareness domain emphasised to enhance their knowledge, information and insight about their emotions which can reduce their vulnerability and negative emotions. The self-management domain provided them skills to regulate their emotional problems and have the ability to cope up with different situations. The social awareness domain helps them manage themselves while interacting with other people. Relationship management domain enhances their capability in managing their emotions with others. By instilling these four domains activities in adolescents, they can enhance their emotional competency in dealing with daily challenges and they can be more goal-focused and self-directed which ultimately increase their psychological well-being.

\section{Acknowledgment}

This study was conducted under the Fundamental Research Grant Scheme

(FRGS/1/2017/SS05/UPSI/02/6) with the permission from the Malaysian Higher Education Ministry.

\section{References}

Castillo, R., Salguero, J. M., Fernandez-Beroccal, P. \& Balluerka, N. (2013). Effects of an emotional intelligence intervention on aggression and empathy among adolescents. Journal of Adolescence, 36(5), 883-892

Castilho, P., Carvalho, S. A., Marques, S., \& Pinto-Gouveia, J. (2017). Self-compassion and emotional intelligence in adolescence: a multigroup mediational study of the impact of shame memories on depressive symptoms. Journal of Child and Family Studies, 26(3), 759-768.

Curtis, A. C. (2015). Defining adolescence. Journal of Adolescent and Family Health, 7(2).

Chong, A. M., Lee, P. G., Roslan, S., \& Baba, M. (2015). Emotional intelligence and at-risk students. SAGE Open, 5(1).

Garaigordobil, M. \& Pena-Sarrionandia, A. (2015). Effects of an emotional intelligence program in variables related to the prevention of violence. Frontiers in Psychology, 6 (743), 1-11.

Goleman, D. (2001). An El-based theory of performance. In C. Cherniss \& D. Goleman (Eds.), The emotionally intelligent workplace (pp. 27-44).

Hajibabaee, F., Farahani, M. A., Ameri, Z., Salehi, T. \& Hosseini, A. F. (2018). The relationship between empathy and emotional intelligence among Iranian nursing students. International Journal of Medical Education, 9, 239-243.

Hashim, I. H. M. (2007). Stress, coping and social supports in the adolescent years. Kajian Malaysia, 25, 97-115.

Krishnan, H. A. (2012). Emotional intelligence of Malaysian youths. Malaysian Journal of Youth Studies, 7, 125-135.

Hodzic, S., Ripoll, P., Bernal, C. \& Zenasni, F. (2015). The effects of emotional competences training among unemployed adults: A longitudinal study. Applied Psychology: Health and Well-Being. 7(3), 275-292

Jafar, S., Aishah, S. H., Aminah, A., \& Maznah, B. (2010). Exploring the relationship of emotional intelligence with mental health among early adolescents. International Journal of Psychological Studies, 2(2), 209-216. 
Ahmad, J., Hassan, A., \& Abidin, N. Z. (2008). Developing, validity and reliability of a drug addiction module among drug addicts who undergoing treatment at rehabilitation centers. The Journal of International Social Research. 1(5), 47-57

Ahmad, J., Yusof, R., Alias, S. R., \& Amat, M. A. C. (2011). The construction, validity, reliability and effectiveness of drug rehabilitation module on self-concept of female addicts and motivation achievement of male addicts in Malaysia. International Journal of Humanities and Social Science, 1(10), 217-228.

Jasmi, A. T., Zakaria, M., \& Norwaliza, A. W. (2015). Validity and reliability of career exploration model. Middle-East Journal of Scientific Research, 23(11), 2639-2644. 8

Lim, T. S. (2011). Gender differences in emotional intelligence: are you as smart as you think emotionally? (April), 1-68.

Liu, Y., Wang, Z., \& Lü, W. (2013). Resilience and affect balance as mediators between trait emotional intelligence and life satisfaction. Personality and Individual Differences.

Motamedi, F., Ghobari-Bonab, B., Beh-pajooh, A., Shokoohi Yekta, M., \& Afrooz, G. A. (2017). Developing an emotional intelligence program training and study its effectiveness on emotional intelligence of adolescents with emotional and behavioral problems that living in single parent families. Journal of Education and Learning, 6(2), 101.

Muhamad Saiful Bahri, Y., Ahmad Fuad, A. R., \& Ab Rahman, E. (2010). The USM Emotional quotient inventory (USMEQ-i) manual. Malaysia: KKMED Publications

Najib, A. M., Che Su, M. \& Zarina, M. S. (2015). Emotional intelligence: Its relationship with communication and information technology skills. Asian Social Science, 11(15), 267-274.

Nareman Aly Mohamed, S. A. A. L., \& Nagwan Mohamed Madbouly \& Eman A. Monem A. Rashid. (2017). The effect of emotional intelligence enhancement program on suicidal ideations among attempted suicide adolescents. IMPACT: International Journal of Research in Applied, Natural and Social Sciences (IMPACT: IJRANSS), 5(11), 111-120.

Noghabaei, M.S. \& Azar, Z.A. (2015). The impact of assertiveness training on high school students' emotional quotient (EQ) in Tehran. European Online Journal of Natural and Social Sciences, 4(2), 323-328.

Azilah, N. L. H., Najmuddin, S. S. H., \& Ruslan, H. (2016). Examining the level of emotional intelligence among semester one students in Universii teknologi MARA Pahang. Journal of Human Capital Development, 9(1), 1-11.

Perveen, A., Hamzah, H., Kee, P., Abas, N. A. H., Othman, A., Morgul, E., \& Daud, N. A. M. (2018). The difference in youth emotional competency level between gender, and institutes, Tunas Bakti, secondary school and university students. International Journal of Education, Psychology and Counselling, 3 (21), 108-117

Perveen, A., Hamzah, H., Kee, P., Daud, N. A. B. M., Othman, A., Abas, N. A. H., \& Morgul, E. (2018). Emotional competency issues faced by youths in Malaysia. International Journal of Academic Research in Business and Social Sciences, 8(11), 1039-1055.

Platsidou, M., \& Tsirogiannidou, E. (2016). Enhancement of emotional intelligence, family communication, and family satisfaction via a parent educational program. Journal of Adult Development, 23(4), 245-253. 
Romero, C., Master, A., Paunesku, D., Dweck, C. S., \& Gross, J. J. (2014). Academic and emotional functioning in middle school: The role of implicit theories. Emotion, 14(2), 227-234.

Russell, J.D. (1974). Modular instructions: A guide to the design, selection, utilization and evaluation of modular materials. Minnesota: Burgee Publication Company.

Salim, S. S. S., Arip, M. A. S. M., Mustafa, M. B., Taff, M. A. M., Khairani, M. Z., \& Yasin, M. H. M. (2018). Construction and validity testing of content specialist encouragement of Emotional Intelligence Module (EeiM). International Journal of Academic Research in Business and Social Sciences, 8(4), 853-860.

Azeem, S., Hassan, B. U. M. (2014). Relationship between emotional intelligence and selfreported delinquency among college boys. Pakistan Journal of Psychology, 45(June), 67-84.

Sidek, M. N., \& Jamaludin, A. (2005). Module building: How to build exercise module and academic module. Serdang: University Putra Malaysia Publisher.

Taghizadeh, B., Masoompour, A., \& Shrinabadi, A. (2017). Effectiveness of emotional intelligence training on the quality of life of mothers of children with leukemia, 1(1).

Toyota, H. (2011). Differences in relationship between emotional intelligence and self-acceptance as function of gender and lbasho (a person who eases the mind) of Japanese undergraduates. Psychological Topics 20, 3, 449-459.

Toyota, H., Oga, K., \& Okamura, T. (2007). Ibasyo to zyoudou chinou ga kodokukan ni ataeru eikyou [Effects of Ibasyo "the person who eases your mind" and emotional intelligence on loneliness]. Nara kyouiku daigaku kiyou [Bulletin of Nara University of Education], 56, 41-45.

Tuckman, B.W. (1999). Conducting educational research (5 $\left.5^{\text {th }} \mathrm{Ed}\right)$. Belmont Wadsworth: Thomson Learning

Vijayalaxmi, A. H. M \& Manjula, K. (2013). Influence of emotional intelligence program to nurture emotional intelligence skills among adolescents. International Journal of Educational Research, 1(1), 26-33.

Wilks, D. C., Neto, F., \& Mavroveli, S. (2015). Trait emotional intelligence, forgiveness, and gratitude in Cape Verdean and Portuguese students. South African Journal of Psychology, 45(1), 93101.

Zijlmans, L. J. M., Embregts, P. J. C. M., Gerits, L., Bosman, A. M. T., \& Derksen, J. J. L. (2015). The effectiveness of staff training focused on increasing emotional intelligence and improving interaction between support staff and clients. Journal of Intellectual Disability Research, 59(7), 599-612 